\title{
Efficacy and Safety of Ethanol Ablation for Branchial Cleft Cysts
}

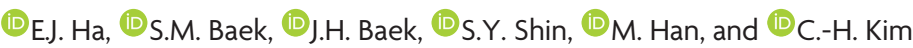

\begin{abstract}
BACKGROUND AND PURPOSE: Branchial cleft cyst is a common congenital lesion of the neck. This study evaluated the efficacy and safety of ethanol ablation as an alternative treatment to surgery for branchial cleft cyst.

MATERIALS AND METHODS: Between September 2006 and October 2016, ethanol ablation was performed in 22 patients who refused an operation for a second branchial cleft cyst. After the exclusion of 2 patients who were lost to follow-up, the data of 20 patients were retrospectively evaluated. All index masses were confirmed as benign before treatment. Sonography-guided aspiration of the cystic fluid was followed by injection of absolute ethanol (99\%) into the lesion. The injected volume of ethanol was $50 \%-80 \%$ of the volume of fluid aspirated. Therapeutic outcome, including the volume reduction ratio, therapeutic success rate (volume reduction ratio of $>50 \%$ and/or no palpable mass), and complications, was evaluated.

RESULTS: The mean index volume of the cysts was $26.4 \pm 15.7 \mathrm{~mL}$ (range, $3.8-49.9 \mathrm{~mL}$ ). After ablation, the mean volume of the cysts decreased to $1.2 \pm 1.1 \mathrm{~mL}$ (range, $0.0-3.5 \mathrm{~mL}$ ). The mean volume reduction ratio at last follow-up was $93.9 \% \pm 7.9 \%$ (range, $75.5 \%-100.0 \%$; $P<.001)$. Therapeutic success was achieved in all nodules $(20 / 20,100 \%)$, and the symptomatic $(P<.001)$ and cosmetic $(P<.001)$ scores had improved significantly by the last follow-up. In 1 patient, intracystic hemorrhage developed during the aspiration; however, no major complications occurred in any patient.
\end{abstract}

CONCLUSIONS: Ethanol ablation is an effective and safe treatment for patients with branchial cleft cysts who refuse, or are ineligible for, an operation.

ABBREVIATIONS: $\mathrm{BCC}=$ branchial cleft cyst; $\mathrm{EA}=$ ethanol ablation; US = ultrasonography

B ranchial cleft cyst (BCC) is a congenital epithelial cyst, which may arise in the lateral neck. The lesions are thought to represent failed obliteration of one of the brachial clefts during embryonic development. ${ }^{1}$ Although BCC is benign, some patients have pain, swelling, neck discomfort, and cosmetic problems. Surgery is curative in patients with BCC, but in addition to the need for general anesthesia, its drawbacks include scarring and postoperative morbidity. Therefore, minimally invasive treatment such as ultrasonography (US)-

Received January 28, 2017; accepted after revision July 10.

From the Departments of Radiology (E.J.H., M.H.) and Otolaryngology (C.-H.K.), Ajou University School of Medicine, Suwon, Korea; Department of Radiology (S.M.B., S.Y.S.), Sharing and Happiness Hospital, Busan, Korea; and Department of Radiology and Research (J.H.B.), Institute of Radiology, University of Ulsan College of Medicine, Asan Medical Center, Seoul, Korea.

Please address correspondence to Seon Mi Baek, MD, Department of Radiology, Sharing and Happiness Hospital, Haeundae-gu, Busan 613-101, Korea; e-mail: radbsm@nate.com

http://dx.doi.org/10.3174/ajnr.A5373 guided chemical ablation has been suggested as an alternative treatment for BCC. ${ }^{2-7}$

Both chemical ablation with picibanil (OK-432) and ethanol ablation (EA) are widely used to treat cystic lesions of the neck and oral cavity, such as thyroid cyst, ranula, and lymphatic malformation, ${ }^{8-13}$ but only a few studies have focused on the use of either treatment in BCCs. Since Fukumoto et $\mathrm{al}^{2}$ initially used EA on 3 BCCs in 1994, several studies have reported success rates of roughly $60 \%$ in patients with BCC treated with OK-432. ${ }^{3-7}$ However, OK-432 is not widely accepted as an alternative to an operation because of its limited efficacy and adverse effects such as fever and local pain after the procedure. ${ }^{3-7}$ In patients with thyroid cysts, EA has been recommended as a first-line treatment technique, rather than OK-432, due to its higher efficacy and safety. ${ }^{14-17}$ However, except for a case report by Fukumoto et al, there have been no studies on the efficacy and safety of EA in BCC, to our knowledge. Therefore, in this retrospective study, we evaluated the efficacy and safety of EA for the treatment of BCC in patients from 2 hospitals (Ajou Univeristy Medical Center, Sharing and Happiness Hospital). 


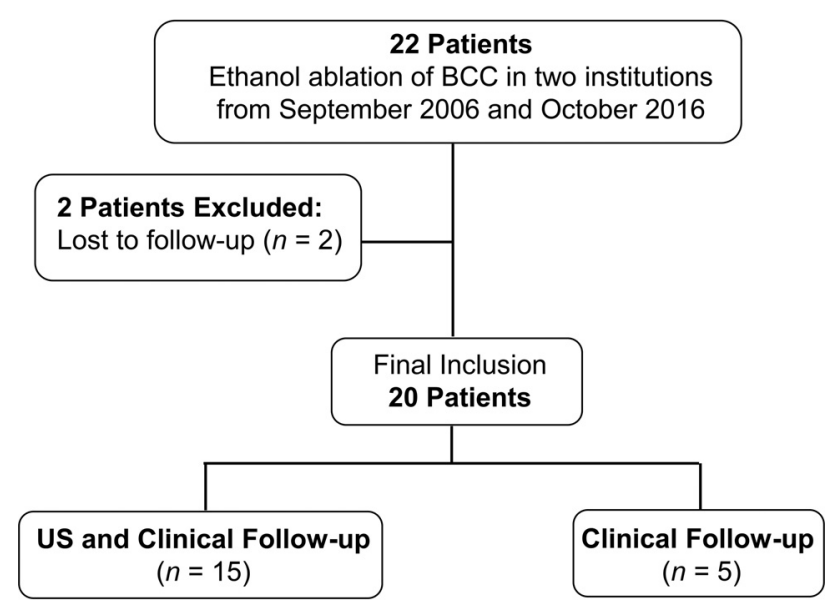

FIG 1. Flowchart of the patient enrollment process.

\section{MATERIALS AND METHODS}

This retrospective study was approved by the institutional review boards of the 2 participating hospitals. Written informed consent was obtained from all patients before the EA procedure.

\section{Patients}

Between September 2006 and October 2016, EA was performed in 22 patients who presented with a second BCC. After the exclusion of 2 patients who were lost to follow-up (Fig 1), 20 patients were included in this study (male/female ratio $=8: 12$; mean age, 30.9 years; range, 2-72 years). All of the included patients fulfilled the following criteria: cosmetic problems and/or symptoms, such as pain, swelling, or neck discomfort; a single clinically palpable neck mass in the anterolateral aspect of the neck (ie, posterolateral to the submandibular gland, lateral to the carotid space, anteromedial to the sternocleidomastoid muscle) previously diagnosed as a benign lesion by fine-needle aspiration; a completely cystic lesion; recurrence after at least 1 simple aspiration procedure; and refusal of or ineligibility for an operation.

\section{Preprocedural Assessment}

Ultrasonography and US-guided fine-needle aspiration were performed in all patients before EA. Two radiologists (S.M.B. and E.J.H.), with 12 and 17 years of clinical experience, respectively, in performing and evaluating neck US images, conducted all US examinations and US-guided fine-needle aspirations. The former imaging was performed with 1 of 3 US systems: an iU22 ultrasound machine (Philips Healthcare, Best, the Netherlands), Acuson S2000 (Siemens, Erlangen, Germany), or an EUB-7500 HV (Hitachi Medical Systems, Tokyo, Japan). All 3 were equipped with a high-frequency linear probe $(5-14 \mathrm{MHz})$. The index cyst volume was calculated as $V=\pi a b c / 6$, where $V$ is the volume, $a$ is the largest diameter, and $b$ and $c$ are the other 2 perpendicular diameters. Before fine-needle aspiration of the cyst wall, as much of the internal fluid as possible was aspirated with a 23-ga needle. A smear for aspirates and a cell block for internal fluid assessment were prepared for use in cytologic evaluations by an experienced cytologist.

Before the procedure, patients were asked to rate their symptoms on a visual analog scale $(0-10)$. The physicians assigned a cosmetic grading score (grade 1, no palpable mass; grade 2, invis- ible but palpable mass; grade 3, mass visible only to experienced clinician; grade 4 , easily visible mass) to the lesions before the procedure. $^{18}$

\section{Procedure}

EA was performed by the same radiologists (S.M.B. and E.J.H.). The patient was placed in the supine position with mild neck extension. After sterilization of the neck skin, local anesthesia consisting of $2 \%$ lidocaine was applied to the puncture site. A 16or 18-ga needle was then inserted into the cyst under US guidance, and a 10- or 25-mL syringe, depending on the cyst size, was connected to the needle. After aspiration of as much of the cyst content as possible, the cyst wall was irrigated with normal saline to remove the debris coating its inner aspect. Because BCC lumina contain watery or cheesy secretions with exfoliated cells, multiple flushes were usually performed to clear the cystic cavity and enable direct contact of the sclerosing agent with the inner epithelial surface. The same needle was used to inject a volume of $99 \%$ sterile ethanol corresponding to $50 \%-80 \%$ of the aspirated fluid volume. If ethanol leakage through the puncture site was seen on real-time US, the ethanol injection was stopped immediately. After 5-10 minutes with the needle in place, the injected ethanol was removed completely and the needle was withdrawn. The patient was observed for 1 hour postoperatively. Complications arising during or immediately after the procedure were evaluated on the basis of the clinical signs and symptoms. Cosmetic and/or symptomatic problems that were incompletely resolved during the follow-up period were treated by repeat EA.

\section{Follow-Up}

Clinical symptoms, US examination, and complications during the follow-up after EA were evaluated. The volume reduction ratio, calculated as Volume Reduction Ratio $(\%)=\{[$ Initial Volume $(\mathrm{mL})-$ Final Volume $(\mathrm{mL})] \times 100\} /$ Initial Volume, was assessed by US and used to determine the efficacy of EA in treating the nodule. The technical success of EA was defined as a volume reduction ratio of $>50 \%$ and/or no palpable mass at the last follow-up. The occurrence of adverse events during the follow-up period was also investigated to assess EA-related complications.

\section{Statistical Analysis}

Statistical analysis was performed with the SPSS for Windows statistical software package (Version 23.0; IBM, Armonk, New York). The Wilcoxon signed rank test was used to compare nodule volumes, as well as symptomatic and cosmetic scores, before and after EA. The Mann-Whitney $U$ test was used to compare variables between patients treated in single-versus-multiple sessions of EA. A $P$ value $<.05$ was considered to indicate statistical significance.

\section{RESULTS}

Initial characteristics of the patients and lesions, treatment characteristics, and changes in the volume of the BCCs after-versusbefore EA are summarized in Table 1. All BCCs contained whiteto-yellowish fluid and keratinaceous cellular debris. Of the 20 nodules, $9(45.0 \%)$ were treated in a single session, and 11 (55.0\%), in multiple sessions (twice, $n=8$; three times, $n=2$; six 
Table 1: Initial patient, brachial cleft cyst, and treatment characteristics and changes in the cysts (before versus after ethanol ablation)

\begin{tabular}{|c|c|c|c|c|c|c|c|c|c|c|c|c|}
\hline \multirow[b]{2}{*}{ Patient } & \multirow[b]{2}{*}{ Sex } & \multirow[b]{2}{*}{$\begin{array}{l}\text { Age } \\
\text { (yr) }\end{array}$} & \multirow[b]{2}{*}{$\begin{array}{c}\text { Index } \\
\text { Volume } \\
\text { (mL) }\end{array}$} & \multirow[b]{2}{*}{$\begin{array}{c}\text { Aspiration } \\
\text { Volume }(\mathrm{mL})\end{array}$} & \multirow[b]{2}{*}{$\begin{array}{c}\text { Ethanol } \\
\text { Volume } \\
\text { (mL) }\end{array}$} & \multirow[b]{2}{*}{$\begin{array}{l}\text { Treatment } \\
\text { Sessions } \\
\text { (No.) }\end{array}$} & \multicolumn{4}{|c|}{ Fluid Volume $(\mathrm{mL})$ at Follow-Up } & \multirow[b]{2}{*}{$\begin{array}{l}\text { VRR } \\
(\%)\end{array}$} & \multirow[b]{2}{*}{$\begin{array}{l}\text { Therapeutic } \\
\text { Success }\end{array}$} \\
\hline & & & & & & & $\begin{array}{l}1-2 \mathrm{mo} \\
(n=17)\end{array}$ & $\begin{array}{c}3-6 \text { mo } \\
(n=9)\end{array}$ & $\begin{array}{c}7-12 \text { mo } \\
(n=7)\end{array}$ & $\begin{array}{c}\text { Final } \\
\text { Evaluation } \\
(n=15)\end{array}$ & & \\
\hline 1 & $M$ & 17 & 29.4 & 30.0 & 10 & 2 & & & $57.9^{\mathrm{a}}$ & $0.4(14)$ & 98.6 & Yes \\
\hline 2 & $\mathrm{~F}$ & 13 & 3.8 & 3.0 & 2 & 2 & 1.1 & $4.4^{\mathrm{a}}$ & 0.3 & $0.3(8)$ & 92.1 & Yes \\
\hline 3 & $M$ & 33 & 41.4 & 40.0 & 20 & 2 & $35.6^{\mathrm{a}}$ & 2.4 & NA & $2.4(4)$ & 94.2 & Yes \\
\hline 4 & M & 15 & 36.6 & 36.0 & 10 & 2 & $33.7^{\mathrm{a}}$ & 9.7 & 1.2 & $0.1(25)$ & 99.7 & Yes \\
\hline 5 & M & 30 & 49.9 & 50.0 & 20 & 1 & NA & NA & NA & NA (12) & NA & Yes \\
\hline 6 & $\mathrm{~F}$ & 60 & 6.1 & 5.8 & 4 & 1 & 0.2 & 0.2 & & $0.0(18)$ & 100.0 & Yes \\
\hline 7 & $\mathrm{~F}$ & 38 & 38.2 & 20.0 & 10 & 2 & $6.6^{\mathrm{a}}$ & NA & NA & NA (12) & NA & Yes \\
\hline 8 & $\mathrm{~F}$ & 25 & 38.0 & 21.0 & 10 & 6 & $5.7^{\mathrm{a}} / 25.12^{\mathrm{a}}$ & $30.4^{a} / 9.3^{a}$ & 2.2 & $0.5(16)$ & 98.7 & Yes \\
\hline 9 & M & 6 & 12.4 & 12.0 & 4 & 1 & NA & NA & NA & NA (22) & NA & Yes \\
\hline 10 & M & 37 & 42.2 & 31.0 & 10 & 2 & $15.1^{a}$ & 1.2 & 0.3 & $0.3(12)$ & 99.3 & Yes \\
\hline 11 & M & 41 & 7.5 & 7.0 & 7 & 2 & $7.4^{\mathrm{a}}$ & NA & NA & NA (12) & NA & Yes \\
\hline 12 & $\mathrm{~F}$ & 26 & 11.8 & 12.0 & 5 & 1 & 1.4 & 0.4 & NA & $0.4(6)$ & 96.6 & Yes \\
\hline 13 & $\mathrm{~F}$ & 49 & 32.8 & 30.0 & 10 & 1 & 0.8 & NA & NA & $0.8(2)$ & 97.6 & Yes \\
\hline 14 & $\mathrm{~F}$ & 34 & 37.7 & 15.0 & 10 & 2 & $30.3^{\mathrm{a}}$ & NA & NA & NA (12) & NA & Yes \\
\hline 15 & $\mathrm{~F}$ & 22 & 48.1 & 33.0 & 25 & 3 & $116.1^{\mathrm{a}}$ & $86.4^{\mathrm{a}}$ & 2.5 & $2.5(9)$ & 94.8 & Yes \\
\hline 16 & $\mathrm{~F}$ & 25 & 13.9 & 10.0 & 6 & 2 & $13.0^{\mathrm{a}}$ & $4.3^{\mathrm{a}}$ & 2.2 & $2.2(7)$ & 84.2 & Yes \\
\hline 17 & $\mathrm{~F}$ & 32 & 5.5 & 5.0 & 4 & 1 & 1.1 & NA & NA & 1.1 (1) & 80.0 & Yes \\
\hline 18 & $\mathrm{~F}$ & 72 & 25.1 & 17.0 & 20 & 1 & 3.5 & NA & NA & $3.5(1)$ & 86.1 & Yes \\
\hline 19 & M & 2 & 37.6 & 36.0 & 10 & 1 & 0.7 & NA & NA & $0.7(2)$ & 98.1 & Yes \\
\hline 20 & $\mathrm{~F}$ & 38 & 10.6 & 10.0 & 6 & 1 & 2.6 & NA & NA & $2.6(2)$ & 75.5 & Yes \\
\hline Mean & & $30.8 \pm 17.0$ & $26.4 \pm 15.7$ & $21.2 \pm 13.6$ & $10.2 \pm 6.3$ & $1.8 \pm 1.2$ & $17.3 \pm 28.3$ & $15.5 \pm 28.2$ & $9.5 \pm 21.4$ & $1.2 \pm 1.1$ & $93.0 \pm 7.9$ & \\
\hline
\end{tabular}

Note:-VRR indicates volume reduction rate; NA, not available.

${ }^{a}$ Additional EA treatment during the follow-up period. The clinical follow-up duration for each patient is shown in parentheses.

times, $n=1)$. The mean number of ablation sessions was $1.9 \pm$ 1.2 (range, 1-6). Data from the follow-up US examination were available for 15 patients. The other 5 patients refused US examination because they felt well and had no palpable lesion in the treated area of the neck. These 5 patients were followed-up clinically.

The mean index volume of the BCCs was $26.4 \pm 15.7 \mathrm{~mL}$ (range, 3.8-49.9 mL). The mean volume of the aspirated internal content was $21.1 \pm 13.6 \mathrm{~mL}$ (range, $3.0-55.0 \mathrm{~mL}$ ), and the mean amount of ethanol injected was $10.2 \pm 6.3 \mathrm{~mL}$ (range, $2.0-25$ $\mathrm{mL}$ ), corresponding to $50.3 \% \pm 24.4 \%$ of the aspirated volume. The mean follow-up in the 20 patients was $9.9 \pm 7.0$ months (range, 1-25 months). By the last follow-up examination, the volume of the treated BCC had decreased significantly to $1.2 \pm 1.1$ $\mathrm{mL}(P=.001)$, which corresponded to a mean volume reduction at the last follow-up examination of $93.0 \% \pm 7.9 \%$. Technical success was achieved in all patients (20/20, 100\%). The mean symptomatic and cosmetic grading scores improved significantly, from $9.2 \pm 1.7$ to $0.6 \pm 0.8(P<.001)$ and from $4.0 \pm 0.0$ to $1.3 \pm$ 0.4 , respectively $(P<.001)$.

Additional EA was performed in 11 patients (11/20, 55.0\%) due to incompletely resolved clinical symptoms and cosmetic problems (Table 2). Improvement was achieved in 8 of these patients after the second treatment; the remaining 3 patients still had incompletely resolved clinical symptoms. However, their clinical symptoms and cosmetic problems improved after a third session of EA in 2 patients and a sixth session of EA in 1 patient, respectively (Fig 2). In patients undergoing multiple treatment sessions, the mean index volume of the cyst was larger, and the initial symptom score, therefore, higher, than in patients treated in a single session. After the procedure, the volume of BCCs in patients in both groups improved significantly, as did the symptomatic and cosmetic scores. Intracystic hemorrhage developed during the aspiration in 1 patient, which delayed the procedure (Fig 3); however, there were no significant complications such as in-
Table 2: Efficacy of ethanol ablation according to the number of treatment sessions ${ }^{a}$

\begin{tabular}{lccc}
\hline No. of Sessions & $\begin{array}{c}\text { Single Session } \\
(\boldsymbol{n}=\mathbf{9})\end{array}$ & $\begin{array}{c}\text { Multiple Sessions } \\
(\boldsymbol{n}=11)\end{array}$ & $\boldsymbol{P}$ Value \\
\hline Initial volume & $21.3 \pm 15.8$ & $30.6 \pm 15.3$ & .160 \\
Symptom score & $8.1 \pm 2.2$ & $10.0 \pm 0.0$ & .011 \\
Cosmetic score & $3.9(3-4)$ & $4.0(4)$ & .710 \\
Final volume (VRR) & $1.3 \pm 1.3$ & $1.1 \pm 1.1$ & .487 \\
$\quad P$ value & .028 & .018 & \\
Symptomatic score & $0.4(0-1)$ & $0.5(0-2)$ & .809 \\
$\quad P$ value & .017 & .004 & \\
Cosmetic score & $1.2(1-2)$ & $1.2(1-2)$ & .827 \\
$\quad P$ value & .009 & .003 & \\
\hline
\end{tabular}

Note:-VRR indicates volume reduction rate.

${ }^{a}$ Data are means unless otherwise indicated. Range is shown in parentheses.

fection, skin necrosis, fever, or nerve palsy. Only mild local pain related to the procedure occurred.

\section{DISCUSSION}

This study evaluated the efficacy and safety of EA for the treatment of BCCs based on the largest number of cases (drawn from 2 hospitals) reported thus far. The results demonstrated a mean volume reduction in the EA-treated BCCs of $93.0 \%$, as well as improvement in clinical symptoms and cosmetic problems. There were no major complications or procedure-related deaths. After a single session, $55.0 \%$ of the patients had incompletely resolved clinical problems, but they responded well to additional EA, which was effective and safe and had a therapeutic success rate of $100.0 \%$. These results support the use of EA as a first-line treatment for BCC.

BCC is a congenital neck mass that usually manifests as a painless lateral neck mass in children and young adults. ${ }^{1}$ However, it may also be symptomatic, with fever, tenderness, and erythema developing in infected cysts, and may cause a cosmetic problem if it enlarges. Complete surgical resection has been the treatment of choice for BCC, but surgery carries the risk of complications re- 

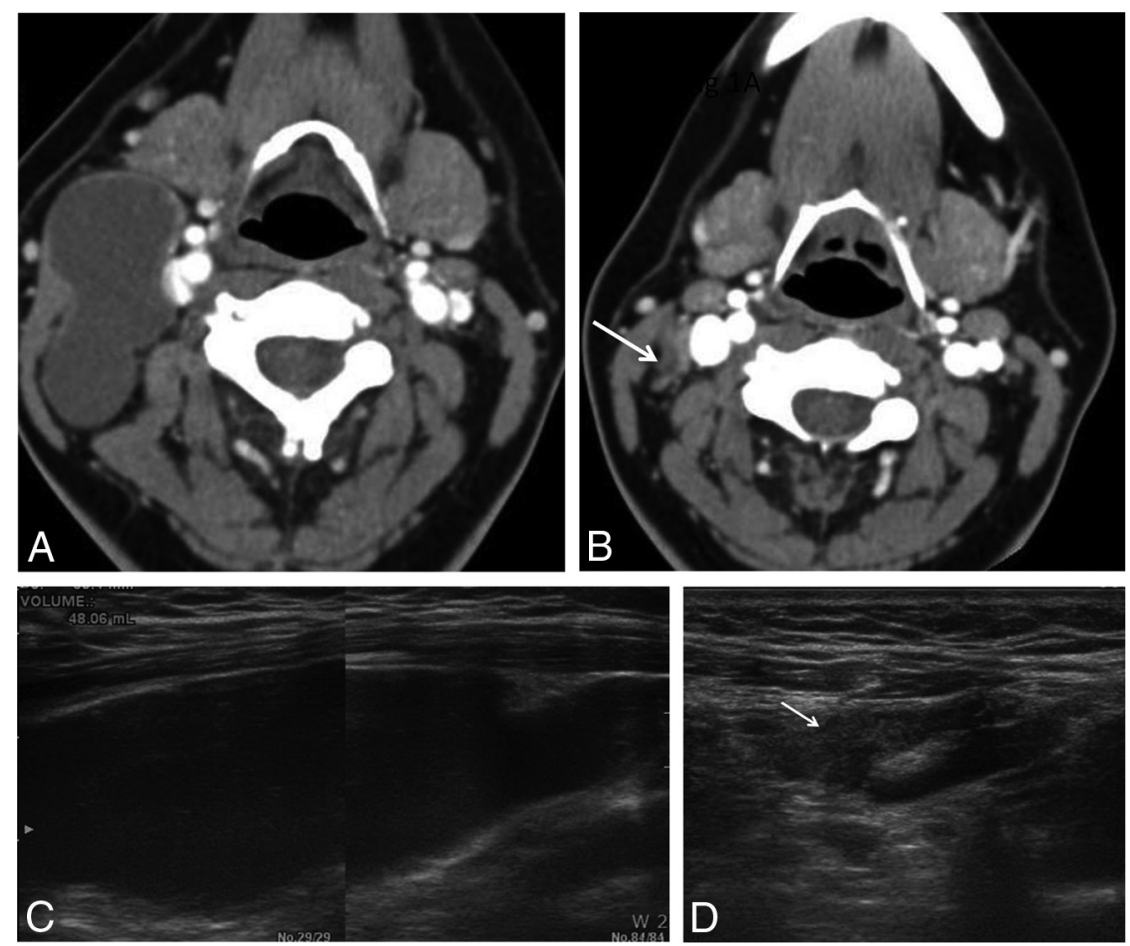

FIG 2. A 22-year-old woman with a right-neck mass. A, A CT scan reveals a $6.5-\mathrm{cm}$ second branchial cleft cyst anteromedial to the sternocleidomastoid muscle and lateral to the carotid sheath. B, After 3 sessions of ethanol ablation, it is nearly obliterated on follow-up CT (arrow). C and $D$, Transverse sonogram also shows a large cystic mass in the right neck (volume, $48.1 \mathrm{~mL}$ ) nearly disappeared after the treatment (arrow).
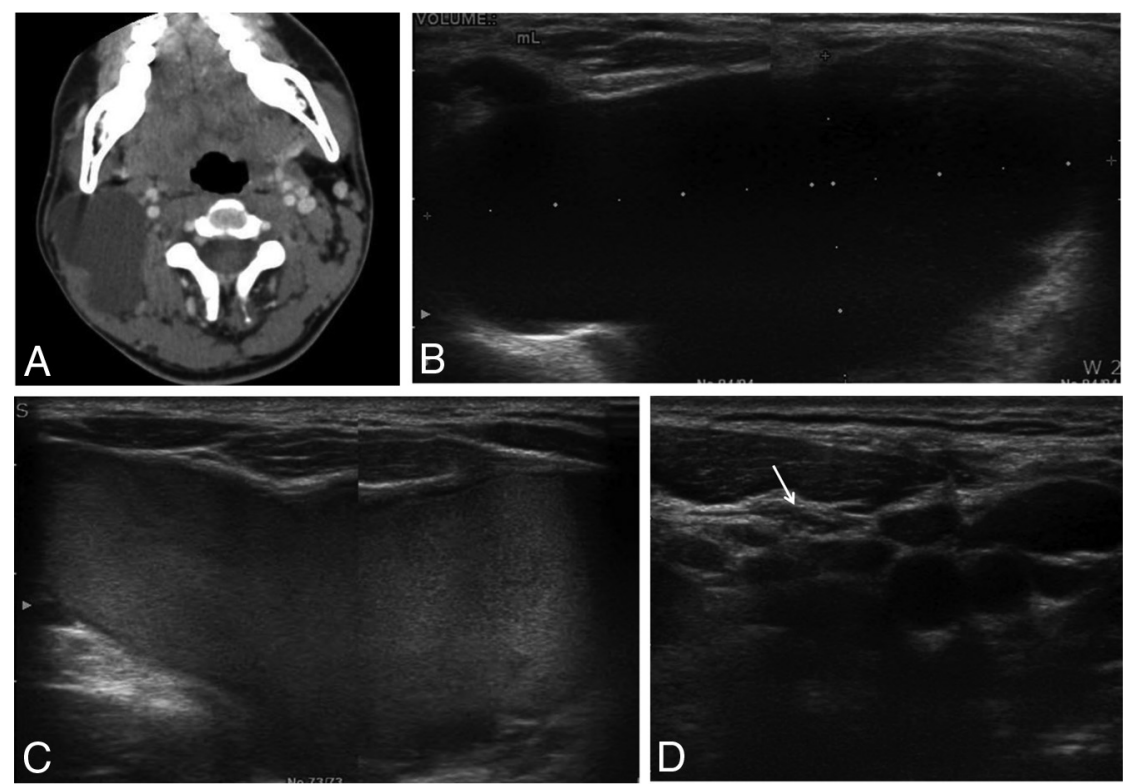

FIG 3. A 15 -year-old adolescent boy with a right-neck mass. $A$ and $B$, Transverse US and CT scans show a 7-cm cystic mass in the right neck (volume, $36.6 \mathrm{~mL}$ ). C, During the ethanol ablation, intracystic hemorrhage developed after aspiration of internal contents. $D$, However, after a second session of ethanol ablation, the cystic mass had disappeared on follow-up US (arrow). come the limitations of surgery. The main advantages of US-guided chemical ablation are the absence of external scarring and the low morbidity and complication rates. ${ }^{3-7}$

OK-432 is a lyophilized mixture of group A Streptococcus pyogenes, which has antineoplastic activity. Despite success rates of $50.0 \%-60.8 \%$ in BCCs treated with OK-432 (Table 3), 25.0\%-41.7\% of patients required an operation due to either partial or no response. ${ }^{3-7,13} \mathrm{OK}-432$ induces a strong inflammatory reaction, including the activation of macrophages and production of cytokines so that fever and local pain develop as adverse effects, though no major complications have been reported. The potential for adverse effects related to the streptococcal preparation, such as post-rheumatic fever sequelae and glomerulonephritis, as well as penicillin-induced anaphylaxis, has also been suggested. ${ }^{7}$ Accordingly, in patients with cystic thyroid nodules, EA may be a better first-line treatment than OK432. ${ }^{14,15,17,20}$ Our study demonstrated a therapeutic success rate with EA higher than that previously reported for OK-432 on the basis of a mean volume reduction ratio in our patients with BCC of $93.0 \%$. Although some patients had mild pain and discomfort related to needle puncture, none had fever or severe pain either during or after treatment, and there were no significant complications.

In terms of the number of treatment sessions, $55 \%(11 / 20)$ of the patients in this study required $>2$ sessions of EA due to incompletely resolved clinical problems after the initial EA. This rate is higher than the reported rate of recurrence after an operation. ${ }^{21-23}$ However, these extra sessions were effective in all cases. The number of patients who required additional EA was higher than the $4.7 \%$ reported in previous studies of patients with thyroid cysts. ${ }^{15}$ This finding may be because the BCC lumen contains watery or cheesy secretions with exfoliated cells, and direct contact of the sclerosing agent with the inner epithelial surface may be difficult. Aspiration of as lated to general anesthesia, postoperative morbidity, and scarring of the surgical wound. In addition, surgeons may be reluctant to undertake open surgical treatment, which might seem inappropriate, particularly in view of the often relatively mild symptomatology. ${ }^{19}$ Alternative treatment of BCCs, specifically US-guided chemical ablation with OK-432 or EA, has been suggested to over- much of the cystic content as possible and irrigation of the cyst wall with normal saline may increase the efficacy of EA by removing the debris or viscous material coating the inner wall of the cyst. ${ }^{24}$ Another possible explanation is that the BCC wall may be thicker than the wall of thyroid cysts; this feature makes complete penetration by the ethanol difficult. Although BCCs are usually 
Table 3: Summary of published data for chemical ablation in patients with brachial cleft cysts ${ }^{\mathrm{a}}$

\begin{tabular}{|c|c|c|c|c|c|c|c|c|c|}
\hline Study & Year & $\begin{array}{l}\text { No. of } \\
\text { Patients }\end{array}$ & $\begin{array}{l}\text { Sclerosing } \\
\text { Agent }\end{array}$ & $\begin{array}{c}\text { Mean Treatment } \\
\text { Sessions (No.) }\end{array}$ & $\begin{array}{l}\text { Complete } \\
\text { Response }\end{array}$ & $\begin{array}{c}\text { Partial ( } \geq 50 \%) \\
\text { Response }\end{array}$ & $\begin{array}{c}\text { Partial (<50\%) } \\
\text { Response }\end{array}$ & $\begin{array}{c}\text { No } \\
\text { Response }\end{array}$ & Complications \\
\hline Fukumoto et $\mathrm{al}^{2}$ & 1994 & 3 & Ethanol & 1.0 & $100.0 \%(3 / 3)$ & - & & - & None \\
\hline Roh et $\mathrm{al}^{5}$ & 2006 & 12 & OK-432 & 2.3 & $58.3 \%(7 / 12)$ & $25.0 \%(3 / 12)$ & & $16.7 \%(2 / 12)$ & Fever \\
\hline Kim et $\mathrm{al}^{4}$ & 2009 & 23 & OK-432 & 1.7 & $60.8 \%(14 / 23)$ & $13.0 \%(3 / 23)$ & $8.7 \%(2 / 23)$ & $17.4 \%(4 / 23)$ & Fever, local pain \\
\hline Ohta et $\mathrm{al}^{6}$ & 2010 & 12 & OK-432 & 2.9 & $50.0 \%(6 / 12)$ & $16.7 \%(2 / 12)$ & $8.3 \%(1 / 12)$ & $25.0 \%(3 / 12)$ & Fever \\
\hline
\end{tabular}

${ }^{a}$ Numbers in parentheses are the numbers of patients among all those included in the study.

lined with a stratified squamous epithelium, in some cases, the lining consists of a thick columnar ciliated epithelium surrounded by dense lymphoid tissue. There may also be marked inflammatory changes and the epithelium may be attenuated. ${ }^{25}$ Thus, a longer ethanol retention time may be needed for BCCs than for thyroid cysts because slower diffusion of the ethanol would induce continuous ablation. A previous study of cystic thyroid nodules (cystic component of $\geq 50 \%$ ) demonstrated a higher therapeutic success rate in a group of patients treated with a longer ethanol retention time, suggesting that this would also be the case in EA-treated BCCs. ${ }^{26}$

Despite the need for additional EA, technical success was achieved in all patients. This is in contrast to the repeat treatment of cystic thyroid nodules, as in $5 \%-25 \%$ of patients refractory to the first round of EA and there was a marked decline in the therapeutic efficacy of subsequent rounds. ${ }^{27}$ Bennedbaek and Hegedüs ${ }^{28}$ also reported a decrease in the efficacy of additional EA in patients with thyroid cysts: $63.6 \%$ after the first, $33.3 \%$ after the second, and $25 \%$ after the third round of EA. However, in our patients with BCCs, additional EA was effective; $45 \%(9 / 20)$ of the patients were treated successfully with 1 round; $81.8 \%(9 / 11)$, with 2 rounds; and $50 \%(1 / 2)$, with 3 rounds. In BCC, the additional EA probably destroys the remaining viable epithelial cell layer that was not in contact with ethanol in the previous ablation, whereas in thyroid nodules, the solid component is more resistant to ethanol diffusion and is likely to bleed, as reported in previous retrospective and prospective studies. ${ }^{27,29}$

In our study, all BCCs were cytologically confirmed as benign at fine-needle aspiration. Nonetheless, CT was performed to exclude the possibility of solitary cystic lymph node metastasis from head and neck cancers. ${ }^{13,30,31}$ A cystic lymph node metastasis from an occult tumor can mimic a benign BCC, and their cytologic features may not be distinguishable by fine-needle aspiration. Thus, especially in older patients, careful evaluation of the imaging features is a prerequisite of EA application. The possibility of a carcinoma arising from a BCC is extremely low and may even be zero. ${ }^{32}$

There were several limitations to this study. First, because the mean follow-up was relatively short, it did not allow an accurate evaluation of recurrence. Second, the number of patients included was small. However, BCC is relatively uncommon, and EA is currently not a primary treatment method for these cysts. Only patients who refused or were ineligible for an operation were included in this study. Therefore, the generalizability of these results may be limited. However, this study of the efficacy of EA for the treatment of BCC is the largest conducted thus far and serves as a basis for further, larger scale studies. Third, only patients with unilocular cystic lesions were included. The effects of EA on other types of brachial sinuses or fistulas may be different.

\section{CONCLUSIONS}

Our results demonstrated that EA offers an effective and safe alternative treatment for patients with BCC who refuse or are ineligible for an operation. It should, therefore, also be considered as a first-line treatment in patients with BCC.

\section{REFERENCES}

1. Benson MT, Dalen K, Mancuso AA, et al. Congenital anomalies of the branchial apparatus: embryology and pathologic anatomy. $R a-$ diographics 1992;12:943-60 CrossRef Medline

2. Fukumoto K, Kojima T, Tomonari H, et al. Ethanol injection sclerotherapy for Baker's cyst, thyroglossal duct cyst, and branchial cleft cyst. Ann Plast Surg 1994;33:615-19 CrossRef Medline

3. Kim MG, Kim SG, Lee JH, et al. The therapeutic effect of OK-432 (picibanil) sclerotherapy for benign neck cysts. Laryngoscope 2008; 118:2177-81 CrossRef Medline

4. Kim MG, Lee NH, Ban JH, et al. Sclerotherapy of branchial cleft cysts using OK-432. Otolaryngol Head Neck Surg 2009;141:329-34 CrossRef Medline

5. Roh JL, Sung MW, Kim KH, et al. Treatment of branchial cleft cyst with intracystic injection of OK-432. Acta Otolaryngol 2006;126: 510-14 CrossRef Medline

6. Ohta N, Fukase S, Suzuki Y, et al. Treatments of various otolaryngological cystic diseases by OK-4321: its indications and limitations. Laryngoscope 2010;120:2193-96 CrossRef Medline

7. Ohta N, Fukase S, Watanabe T, et al. Effects and mechanism of OK432 therapy in various neck cystic lesions. Acta Otolaryngol 2010; 130:1287-92 CrossRef Medline

8. Lee DK, Seo JW, Park HS, et al. Efficacy of ethanol ablation for thyroglossal duct cyst. Ann Otol Rhinol Laryngol 2015;124:62-67 CrossRef Medline

9. Sung JY, Baek JH, Kim KS, et al. Symptomatic nonfunctioning parathyroid cysts: role of simple aspiration and ethanol ablation. Eur J Radiol 2013;82:316-20 CrossRef Medline

10. Sung MW, Lee DW, Kim DY, et al. Sclerotherapy with picibanil (OK-432) for congenital lymphatic malformation in the head and neck. Laryngoscope 2001;111:1430-33 CrossRef Medline

11. Tu JH, Do HM, Patel V, et al. Sclerotherapy for lymphatic malformations of the head and neck in the pediatric population. J Neurointerv Surg 2016 Oct 5. [Epub ahead of print] CrossRef Medline

12. Kim KH, Sung MW, Roh JL, et al. Sclerotherapy for congenital lesions in the head and neck. Otolaryngol Head Neck Surg 2004;131: 307-16 CrossRef Medline

13. Kim JH. Ultrasound-guided sclerotherapy for benign non-thyroid cystic mass in the neck. Ultrasonography 2014;33:83-90 CrossRef Medline

14. Gharib H, Hegedüs L, Pacella CM, et al. Clinical review: nonsurgical, image-guided, minimally invasive therapy for thyroid nodules. J Clin Endocrinol Metab 2013;98:3949-57 CrossRef Medline

15. Sung JY, Baek JH, Kim KS, et al. Single-session treatment of benign cystic thyroid nodules with ethanol versus radiofrequency ablation: a prospective randomized study. Radiology 2013;269:293300 CrossRef Medline

16. Sung JY, Baek JH, Kim YS, et al. One-step ethanol ablation of viscous cystic thyroid nodules. AJR Am J Roentgenol 2008;191:1730-33 CrossRef Medline 
17. Sung JY, Kim YS, Choi H, et al. Optimum first-line treatment technique for benign cystic thyroid nodules: ethanol ablation or radiofrequency ablation? AJR Am J Roentgenol 2011;196:W210-14 CrossRef Medline

18. Baek JH, Ha EJ, Choi YJ, et al. Radiofrequency versus ethanol ablation for treating predominantly cystic thyroid nodules: a randomized clinical trial. Korean J Radiol 2015;16:1332-40 CrossRef Medline

19. Nixon PP, Healey AE. Treatment of a branchial sinus tract by sclerotherapy. Dentomaxillofac Radiol 2011;40:130-32 CrossRef Medline

20. Na DG, Lee JH, Jung SL, et al; Korean Society of Thyroid Radiology (KSThR), Korean Society of Radiology. Radiofrequency ablation of benign thyroid nodules and recurrent thyroid cancers: consensus statement and recommendations. Korean J Radiol 2012;13:117-25 CrossRef Medline

21. Spinelli C, Rossi L, Strambi S, et al. Branchial cleft and pouch anomalies in childhood: a report of $\mathbf{5 0}$ surgical cases. J Endocrinol Invest 2016;39:529-35 CrossRef Medline

22. Prasad SC, Azeez A, Thada ND, et al. Branchial anomalies: diagnosis and management. Int J Otolaryngol 2014;2014:237015 CrossRef Medline

23. Ford GR, Balakrishnan A, Evans JN, et al. Branchial cleft and pouch anomalies. J Laryngol Otol 1992;106:137-43 CrossRef Medline

24. Kim SM, Baek JH, Kim YS, et al. Efficacy and safety of ethanol ablation for thyroglossal duct cysts. AJNR Am J Neuroradiol 2011;32: 306-09 CrossRef Medline

25. Thomaidis V, Seretis K, Tamiolakis D, et al. Branchial cysts: a report of 4 cases. Acta Dermatovenerol Alp Pannonica Adria 2006;15:85-89 Medline

26. Kim DW, Rho MH, Kim HJ, et al. Percutaneous ethanol injection for benign cystic thyroid nodules: is aspiration of ethanol-mixed fluid advantageous? AJNR Am J Neuroradiol 2005;26:2122-27 Medline

27. Lee JH, Kim YS, Lee D, et al. Radiofrequency ablation (RFA) of benign thyroid nodules in patients with incompletely resolved clinical problems after ethanol ablation (EA). World J Surg 2010;34:1488-93 CrossRef Medline

28. Bennedbaek FN, Hegedüs L. Treatment of recurrent thyroid cysts with ethanol: a randomized double-blind controlled trial. J Clin Endocrinol Metab 2003;88:5773-77 CrossRef Medline

29. Jang SW, Baek JH, Kim JK, et al. How to manage the patients with unsatisfactory results after ethanol ablation for thyroid nodules: role of radiofrequency ablation. Eur J Radiol 2012;81:905-10 CrossRef Medline

30. Foss RD, Warnock GR, Clark WB, et al. Malignant cyst of the lateral aspect of the neck: branchial cleft carcinoma or metastasis? Oral Surg Oral Med Oral Pathol 1991;71:214-17 CrossRef Medline

31. Briggs RD, Pou AM, Schnadig VJ. Cystic metastasis versus branchial cleft carcinoma: a diagnostic challenge. Laryngoscope 2002;112: 1010-14 CrossRef Medline

32. Girvigian MR, Rechdouni AK, Zeger GD, et al. Squamous cell carcinoma arising in a second branchial cleft cyst. Am J Clin Oncol 2004; 27:96-100 CrossRef Medline 